\title{
A Cultural Comparison of English and Chinese Family Names
}

\author{
Hongmei Zhu \\ School of Foreign languages, Henan University of Technology \\ Lotus Street, Hi-Tech Development Zone, Zhengzhou 450001, Henan, China \\ Tel: 86-371-6775-6797_E-mail: zhuhongmei@haut.edu
}

\begin{abstract}
The family names of humans are formed and used in the long process of the course of history and the development of society. Family names, being a part of culture, are closely related to history and culture. English and Chinese names are different in their origins and name orders, which is certain to be reflected in their perspective culture. Therefore an exploration of their reflections in the cultural aspects of historical development, feudal history, historical tradition, historical influence and current social situation will be beneficial for the deepening of English study and the mutual understanding and communication of the East and the West.
\end{abstract}

Keywords: Cultural comparison, English family names, Chinese family names, Origin, Name order

The word "culture" comes from the Latin root "colere" (to inhabit, to cultivate, or to honor). In general, it refers to human activity; different definitions of culture reflect different theories for understanding, or criteria for valuing, human activity. Culture is traditionally the oldest human character, its significant traces separating Homo from australopithecines, and Man from the Animals, though new discoveries are blurring these edges in our day. Sir Edward B. Tylor wrote in 1871 that "culture or civilization, taken in its wide ethnographic sense, is that complex whole which includes knowledge, belief, art, morals, law, custom, and any other capabilities and habits acquired by man as a member of society" while a 2002 document from the United Nations agency UNESCO states that culture is the "set of distinctive spiritual, material, intellectual and emotional features of society or a social group and that it encompasses, in addition to art and literature, lifestyles, ways of living together, value systems, traditions and beliefs". [UNESCO, 2002]. It is generally accepted that language is part of culture. It carries culture, thus be influenced by culture. Names including family names, which is a part of language, are sure to reflect the distinct culture of the people using it. This paper intends to start from the English and Chinese family names from the perspectives of the origin and order so as to reveal their reflections on their own culture.

A family name (in Western contexts often referred to as a last name or surname) is part of a person's name indicating the family to which the person belongs.A family name is the most fundamental and most significant symbols showing the identification of the members of a society. The use of family names is widespread in cultures around the world, which means family names are part of culture. As far as English and Chinese names are concerned, their cultural differences can be shown in the origins of their family names and the different orders of their names so as to make us learn about the development history of a society or a nation and some other aspects of its culture, which is the purpose of this paper intending to make an analysis between English and Chinese family names from their cultures reflected.

\section{Cultural reflections of the origins of family names}

If we trace back into the origins of Chinese family names, we can see that Chinese family names are closely related to the development history of the Chinese nation. According to legend, family names started with Emperor $\mathrm{Fu} \mathrm{Xi}$ in $2852 \mathrm{BC}$. His administration standardized the naming system in order to facilitate census-taking, and the use of census information. For scientific documentation that matrilineal surnames existed in China before the Shang Dynasty (1600-1046 BC) and that "by the time of the Shang Dynasty they (Chinese surnames) had become patrilinea." Therefore, what we can learn first is that the ancestors of the Chinese nation came from primitive society. When the Chinese nation went into class society, the emperors had the supreme powers in their hands in awarding lands and fields to those ministers who performed meritorious service to their reigns, establishing official positions. Their supreme power was best exemplified in granting a surname to a person when he was alive or after his death. In addition, in feudal societies, the emperors' names was a taboo on every occasions. The origins of family names also showed that Chinese nation actually is combination of multiple nationalities, which is the same case for the British and American people. As for English family names, 
they have a relatively short history. Documents indicate that surnames were first adopted among the feudal nobility and gentry, and only slowly spread to the other parts of society. In Britain, hereditary surnames were adopted in the 13th and 14th centuries, initially by the aristocracy but eventually by everyone. By 1400 , most English and Scottish people had acquired surnames, but many Scottish and Welsh people did not adopt surnames until the 17th century, or even later. Henry VIII (1491-1547) ordered that marital births be recorded under the surname of the father. The whole process lasted for 500 years. However, English family names differ from Chinese family names in their civilians consciousness, which can be shown in the casual choice of their family names for even a nickname, childhood name like Fox, Stout, Armstrong, Longfellow can be a person's family name. The origins of English family names can show their love for nature, respect for and sentimental attachment to everything in it. English family names like Bird, Lion, Swan, Wood, Wolf, Bush, Flower, Rose and Apple are such examples. Their family names also indicated that English people are characterised by the pursuit for novelty and oddness without an exception of their family names. According to a survey made in 1974, there were as many as 1,280,000 family names in America, among which more than 1/3 were those that had never been used before, which was obviously a result of Americans' unconventional and original personality.

\section{Cultural reflections of the order of family names}

\subsection{Reflection of perspective feudal history}

The nations with a name order of family names preceding given names usually have a long feudal history. The Han nationality have a feudal history of more than 2,500 years, which started from the Western Zhou (1066 - 771 BC)or Eastern Zhou (770 - 256 BC) Chinese society to the Opium War in1839. However, the feudal history of those nations with a name order whose given names precede family names is relatively short. Great Britain is a case in point. It only had a short feudal history of several hundred years. From the 9th century to the 11th century, Britain was still on its way to feudalization and there exited a large number of free farmers. It was only after the Norman Conquest of 1066, the feudal system was widely established in Britain. However, only several hundred years later, in the 14th century, its feudal system was disintegrated. When it came to the 16th century, the capitalism was widely developed, which directly led to the British Bourgeois Revolution in the 17th century. To sum up, the feudal history of Britain is very short with no more than 500 years, but its capitalism was developed quite early.

\subsection{Reflection of perspective historical tradition}

The nations with a name order of family names preceding given names usually have a long feudal history, in which there wasn't any democratic tradition and everything was determined by the will of the supreme emperors. Therefore, in those nations, given names which represent a person himself can only be put behind family names which stand for home ownership. In China, from the very beginning of family names, they were put before given names and the tradition lasted for more than 2,500 years. In these nations, although the choice of a person's given names has always been changing with the era, the order of names has always been stable.

On the contrary, the British and American people had their democratic tradition even in the feudal reign, which made these nations strengthened more on individual roles. Therefore, their given name which stands for the individual himself was always put before their family name which is a representation of their family.

\subsection{Reflection of their historical influence}

Chinese name order has a direct influence on that of its neighbouring countries like Korea, Vietnam and Japan because of its 5,000 year history of civilization. China's naming system came into being as early as the reign of Emperor Fu Xi. Its neighbouring countries like Korea, Vietnam and Japan either had long been its dependent country or using Chinese characters as their own language. They were greatly influenced by its culture. Similarly, these countries all had a long feudal history, had no democratic tradition, bordered China, used Chinese characters. Therefore it was no wonder that they were sure to be influenced Chinese cultures including naming system.

However, the English name order was influenced by Roman Republic in its early time. Rome became a republic in about B.C. 510. From then on, the civilians had constant fights against nobility for their rights, which was the origin of their democratic tradition. Because at that time, ancient Rome was the number one civilized country in Europe and in the course of its development it constantly expanded its territories and formed its hegemony in the Mediterranean in the 2nd century B.C., therefore, its democratic tradition had a great influence on the formation of the national psychology of the whole Europe. Ancient Romans' name was spelled in Latin, and freeman's name was formed by given name plus tribe or clan name, which was actually their family name. Take the famous Great Emperor Caesar of ancient Rome for example, his name was formed by three parts, that is Caius, Julius 
and Caesar. With the development of history, the middle name which was one's clan name disappeared with the diminishing power of clan. The Roman name order which strengthened individual role was widely accepted in the Miderterranean with its expansion in this area. The Latin language which was spoken by ancient Romans first replaced other languages in this area but then split into Italian, French, Portugese and Spanish with the fall of the Roman Empire. Because these languages all have Latin origin, it's natural that the name order of the Latin language permeated into their languages.

\section{Reflection of current social situation}

Family names are not only used for addressing people, they also reflect social realities at that time. In China's ancient Zhou Dynasty, having or not having a family name showed the contradictory relation between the ruling class and the working class. Before the establishment of the People's Republic of China, Chinese women followed their husband's family name by abandoning their original family name, which showed the feudal prejudice against and bondage upon them. After the establishment of the P. R.C., the social status of Chinese women has been greatly improved and been considered "half sky", they can keep their own family name when they get married. However, in England and cultures derived from there, there has long been a tradition for a woman to change her surname upon marriage from her birth name to her husband's last name. From the first known US instance of a woman keeping her birth name, Lucy Stone in 1855, there has been a general increase in the rate of women keeping their original name. This has gone through periods of flux, however, and the 1990s saw a decline in the percentage of name retention among women. As of 2004, roughly $90 \%$ of American women automatically assumed their husband's surname upon getting married. Even in families where the wife has kept her birth name, parents traditionally choose to give their children their father's family name. Although in America, there was a great change for married women traditionally known as Mrs [Husband's full name] into a modern Mrs [Husband's last name], the incompleteness of women's liberation can still be shown from this.

To sum up, family names are not only a sign for a person but reflect culture from different aspects. And a comparison of English and Chinese family names can make us learn about the cultural differences shown from the origins and name orders, which is good for the deepening of the study of English as well as helps to promote the mutual understanding and communication of the East and the West.

\section{References}

Danesi, Marcel. (2007). The Quest for Meaning. Toronto: University of Toronto Press, p 48.

Doll, Cynthia Blevins. (1992). Harmonizing Filial and Parental Rights in Names: Progress, Pitfalls, and Constitutional Problems. Howard Law Journal (Howard University School of Law) 35.

Kramsch, Claire. (2000). Language and Culture. Shanghai: Shanghai Education Pres.

Wang, Quangen. (1988). Perspectives of Chinese Personal Names. Nanning: Guangxi People's Publishing House.

Wang, Quangen. (2001). Culture of Chinese Personal Names. Beijing: Unity Press.

Wiehl, Lisa. (2008). Wedding Norms Challenged as Women Question Changing Names, Fox News. Retrieved October 14. 